\title{
Agro-morphological Diversity of High Altitude Bean Landraces in the Kailash Sacred Landscape of Nepal
}

\author{
Kamal Aryal ${ }^{1,3}$, , Sushmita Poudel ${ }^{2}$, Pashupati Chaudhary ${ }^{1}$, Ram Prasad Chaudhary ${ }^{3}$, Krishna Hari \\ Ghimire $^{4}$, Deepa Singh Shrestha ${ }^{4}$ and Bal Krishna Joshi ${ }^{4}$
}

IInternational Centre for Integrated Mountain Development, Khumaltar, Nepal; @: kamal.aryal@icimod.org; ORCID: https://orcid.org/0000-0001-6154-8844; PC: pashupati.chaudhary@icimod.org

${ }^{2}$ University of California, Santa Cruz, USA; spoudel@ucsc.edu

${ }^{3}$ Research Centre for Applied Science and Technology (RECAST), Tribhuvan University, Nepal: ram.chaudhary53@gmail.com

${ }^{4}$ National Genebank, National Agriculture Research Council, Khumaltar, Nepal; KHG:

krishnahari.ghimire@yahoo.com; DS: dees_shrestha@hotmail.com; BKJ: joshibalak@yahoo.com

Received 07 Dec 2019, Revised 27 Jan 2020, Accepted 14 Feb 2020, Published

17 March 2020

Scientific Editors: Jiban Shrestha, Nabin Bhusal, Umesh Acharya

Copyright $(0) 2020$ NARC. Permits unrestricted use, distribution and

reproduction in any medium provided the original work is properly cited.

The authors declare that there is no conflict of interest.

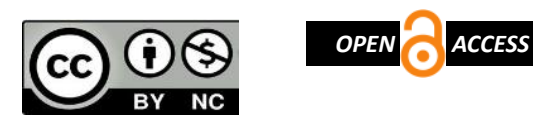

Licensed under the Creative Commons AttributionNonCommercial 4.0 International (CC BY-NC 4.0)

\section{ABSTRACT}

Many varieties of bean are widely grown across diverse agro-ecological zones in Nepal, and opportunities exist for improving the crops and enhancing their resilience to various biotic and abiotic stressors. In this context, an experiment was conducted from June to October 2016 in Khar VDC of Darchula district to study the phenotypic traits of nine landraces of bean (Phaseolus vulgaris L.). The bean landraces were planted using randomized complete block design in three sites (Dhamidera, Dallekh and Sundamunda villages), with three replications in each site for their comparative analysis. The study considered the following phenotypic traits: days to emergence, days to $50 \%$ flowering, days to $90 \%$ pod maturity, number of nodes, pod length, pod width, number of pods, number of seeds per pod and weight and grain yield for 100 seeds. Kruskal-Wallis test showed significant differences in the landraces both within and among locations. KA-17-08-FB and KA-17-04-FB were late flowering (63 and 65 days respectively) compared to other landraces whereas KA-17-07-FB flowered earliest (within 42 days). In all three sites, three landraces namely KA-17-07-FB, KA-17-04-FB and KA-17-06-FB were found to be relatively more resistant to pest and diseases than other landraces. Eight out of nine landraces in Dhamidera and Dallekh villages and seven out of nine in Sundamunda village produced seeds greater than $1.0 \mathrm{t} / \mathrm{ha}$. Among the nine varieties KA-17-02-FB was the highest yielding variety, with an average yield of $3.8 \mathrm{t} / \mathrm{ha}$. This study is useful for identifying suitable landraces for future promotion based on their maturity, grain yield, diseases resistance and other qualitative and quantitative characteristics.

Keywords: Common bean, Landrace, Diversity, Kailash Sacred Landscape, Phenotype

\section{सारांश}

सिमी नेपालको विभिन्न कृषि पर्यावरण भएको ठाउमा लगाउने प्रचलन छ र त्यसको सहि तरिकाको विकास र अनेक किसिमका जैविक तथा अजैविक समस्याहरुसंग जुध्न तथा अनुकलीत गर्ने सम्भावनाहरु प्रचुर छ। विरुवाको आवरणको आधारमा अध्ययन गर्ने उद्देश्यले दार्चलाको खार गा.वि.स. मा $९$ वटा सिमीका स्थानीय जातहरु २०७४ को असार देखि कार्तिक महिनासम्म लगाइको थियो । ती सिमीका जातहरु तुलनात्मक अध्ययनको उद्देश्यले randomized complete block design (RCBD) विधिद्वारा तिन स्थानमा (धामिडेरा, दल्लेख र सुन्डमुन्ड गाउमा) लगाइको थियो र हरेक जात प्रत्येक स्थानमा तिन ठाउमा लगाइएको थियो । अध्ययनले निम्न आवरणसम्बन्धी गुणहरु समेटेको थियो: उम्रिन लागने दिन, पू० प्रतिशत फूल फल्ले दिन, ९० प्रतिशत कोषा पाक्ने दिन, गांठोको संख्या, कोषाको लम्बाइ, कोषाको चौडाइ, कोषा संख्या, प्रति कोषा विड संख्या र $१ ० ०$ दानाको तौल। डाटा विश्लेषण गरी सिमीहरुको जातको बीचमा विशिष्ट रुपले फरक छ छैन हेर्न Kruskal-Wallis विधि अपनाइएको धियो। नौ वटा मध्ये KA-17-08-FB र KA-17-04-FB (कमश: ६३ दिन र ६४ दिनमा फल्ने) जातहरु अलि ढीलो फल्ने पाइयो भने KA-17-07-FB सबैभन्दा चांडै फूल्ने ( $४$ दिन) पाइयो । सबै ठाउमा तिनवटा जातहरु जस्तै: KA-17-07-FB, KA-17-04$\mathrm{FB}$ and KA-17-06-FB अरु जातको तुलनामा अलि बढ़ी रोग र किरा सहन सक्ने पाइयो । वीउको उत्पादनको हकमा, धामिडेरा र 
दल्लेखमा नौ वटा मध्ये अठवटा र सुन्डमुन्डमा नो वटामध्ये सातवटा जातहरु 9 टन प्रति हेक्टरभन्दा बढी भएको पाइयो । नौवटा मध्ये KA17-02-FB सबैभन्दा बढी उत्पादन दिने पाइयो जसको उत्पादन ३.५ टन प्रति हेक्टर मापन गरिएको थियो । यस अध्ययनले पाक्ने समय, उत्पादन, रोग किराको प्रकोप र अन्य गुणहरुको आधारमा स्थानीय ठाउंमा सुहाउदो जातहरु छनौट गर्न मद्दत गर्नेछ।

\section{INTRODUCTION}

Nepal makes for about $0.4 \%$ of the world's pulse-growing area and production capacity. The country's varied climatic and environmental conditions provide prospects for growing many different species of legumes. In Nepal, pulses (including soybeans) are farmed on $10 \%$ of the total cultivated land area, and they rank fourth in terms of cultivated-area size, after rice, wheat, and maize. In total, grain legumes are grown on 311,382 ha of land, with production and productivity figures of 368,741 tons and $1.18 \mathrm{t} / \mathrm{ha}$, respectively (http://agrinepal.blogspot.com/2013/07/status-and-future-prospects-ofpulses.html). Different types of legumes are cultivated and consumed as vegetables and pulses in Nepal. Legumes are very important source of protein for marginal farmers as well as vegan people. They also enrich nitrogen and organic matter to the soil. About $32.2 \%$ higher nitrogen was found in the fields where legume was inter-cropped with maize than the mono-cropped maize fields (Shrestha et al 2008).

Common bean (Phaseolus vulgaris L.) is an important legume cash crop cultivated in a wide range of agro-climatic conditions from Tarai $(300 \mathrm{~m}$ amsl) to high hill $(2500 \mathrm{~m}$ amsl) of Nepal, especially in mountain districts such as Jumla, Humla, Mustang, Rasuwa, Solukhumbu, etc, where mixed landraces with varying morphologies are cultivated. Nepal's hills and mountains are rich in bean diversity, and some landraces have unique characteristics (KC et al 2016, Joshi et al 2017a). Common beans grown in high-hill have better taste and are considered more nutritious compared to the beans grown in Terai region of Nepal. More recently, this crop is commonly grown along with kidney bean, fetches good return and have well established market (Neupane et al 2008, Muchui et al 2008, Shrestha et al 2011, Neupane and Vaidya 2002).

People from low plains (below $500 \mathrm{~m}$ asl) usually plant red kidney beans in the winter as monoculture and it is an important part of cuisine. In the hill (500 - 1600 masl) french beans, both pole and bush types, are cultivated usually during summer to autumn for consuming leaves and fresh green pods as green vegetables. In the high hills and mountains (1600- 2500 masl) dried shelling beans are planted during summer to autumn along with maize and also in apple orchards (Pandey et al 2011).

The research solely on grain legumes is relatively low in Nepal. Limited studies are conducted on french beans in different parts of the country but multi-location trials are rarely done. For instance, Neupane et al (2008) investigated 100 accessions of local and exotic beans using agro-morphological characteristics in order to assess variability and potentials of germplasm for varietal improvement programs. An on-farm evaluation in participatory varietal trials suggested that Jumli farmers preferred PB0001, PB0002, and PB0048 genotypes among the evaluated accessions due to medium growth habit, tolerance to disease early maturing nature, high yielding, good seed size and color (Chhetri and Bhatta 2017). A study conducted at Regional Agriculture Research Station (RARS) Lumle, Kaski by Pandey et al (2011) on 18 exotic and indigenous french bean genotypes of western hills, revealed that there is good variation in bean genotypes. Another study by Pandey et al (2012), conducted to understand the response of pole type french beans to sowing dates, showed significant effects in yield and yield attributes among three different varieties studied. All the yield attributes such as early flowering, widest pods, fresh pod yield, and longest pods were highest in all the varieties planted in mid-August. Mid-August was considered the best time for sowing the crop to obtain the highest pod yield in mid-hill.

The study of agronomical characteristics of genotypes is very important to identify suitable genotypes for an area which can fulfill the needs of marginalized farmers (Sheikh et al 2017) and because of just only two modern varieties (Joshi et al 2017b) in the country. Characterization of agronomical traits also helps to find out useful characters which could be used in breeding programme to enhance grain yield and biotic and abiotic stress tolerance. The main objective of the study was to assess the agro- 
morphological characteristics of the bean landraces available in the study sites and select most suitable landraces for future promotion. It also aimed to produce seeds of the local rare and economically important landraces for the future out-scaling and up-scaling.

\section{MATERIALS AND METHODS}

\section{Geographical location of study area}

The study was conducted in three villages namely Dallekh (2146 masl), Sundamunda (1862 masl) and Dhamidera (1536 masl) of Khar VDC, Darchula, Nepal (Figure 1). The sites were selected as they represent three different elevation gradients with the difference of about 300 meters from Dhamidera to Sundamunda and Dallekh. The sites having similar aspects (Southeast face), soil and nutrients condition and water availability were identified for the experiments. The site selection was carried out with combined objectives of conducting the experiment and also for the demonstration.

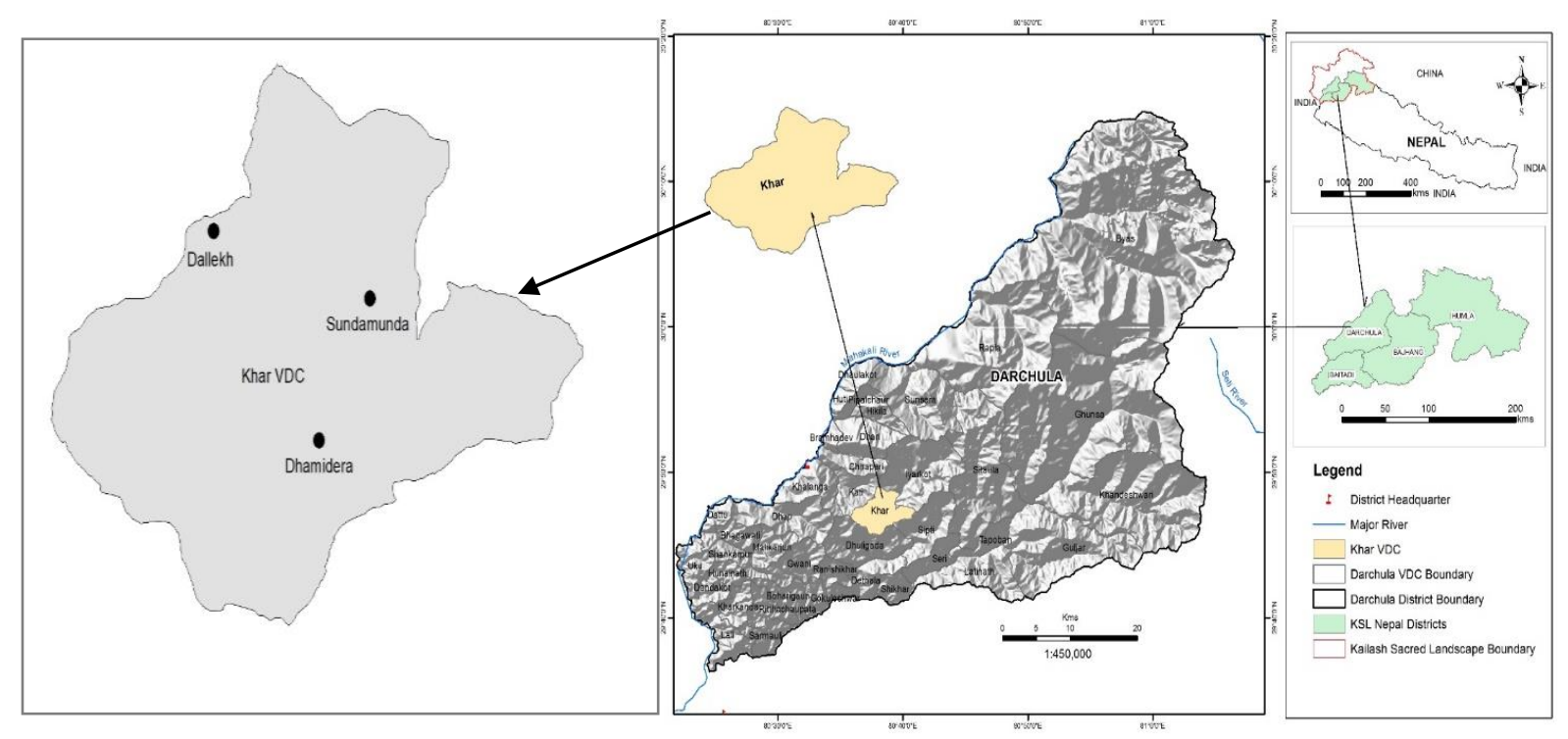

Figure 1. Experimental research sites in Khar.

\section{Establishment of diversity blocks and experimental plots}

The diversity blocks and experimental plots of nine bean varieties were established in three different sites of Khar VDC. The diversity blocks were meant for the display of different varieties of beans grown by the farmers in and around the VDC in order to increase awareness among people. A total of 20 seeds of each variety were sown in the diversity blocks. The beans were planted on $27^{\text {th }}$ June 2016 . The maximum and minimum temperature range during the crop growing period was $22^{\circ} \mathrm{C}$ and $13^{\circ} \mathrm{C}$ in June to $16^{\circ} \mathrm{C}$ and $5^{\circ} \mathrm{C}$ in October.

Besides the diversity blocks, experimental plots were arranged in a randomized complete block design with three replications. The plant to plant distance for the determinate bush type was maintained 60 $\mathrm{cm} \times 20 \mathrm{~cm}$ and the indeterminate type was $75 \mathrm{~cm} \times 30 \mathrm{~cm}$. One treatment consisted of mixed varieties of beans, which was used as control. The cultivation of bean mixture is a common practice in high mountains and especially with landraces. The experimental blocks were managed using local farmers' practice making sure that all the plots in all three sites received same inputs and treatments except genotype. All the seeds planted are collected from farmers from Khar VDC (See Table 1). The beans planted along with the collection number from Genebank are in Table 1. 
Table 1. Details of 9 bean landraces tested along with the collection number from the Genebank

\begin{tabular}{llllll}
\hline \multirow{2}{*}{$\begin{array}{l}\text { Collection } \\
\text { number }\end{array}$} & Local name & \multicolumn{2}{c}{ Collection from } & Grain color \\
\cline { 3 - 5 } & & District & VDC & Altitude $(\mathbf{m})$ & \\
\hline KA-17-08-FB & Seto sotta & Darchula & Khar & $1500-2150$ masl & Creamy White \\
\hline KA-17-07-FB & Temase rato & Darchula & Khar & $1500-2150$ masl & Maroon \\
\hline KA-17-02-FB & Kaleji kirmire & Darchula & Khar & $1500-2150$ masl & Dark blood with white spots \\
\hline KA-17-05-FB & Marma sotta & Darchula & Khar & $1500-2150$ masl & Yellow peach \\
\hline KA-17-09-FB & $\begin{array}{l}\text { Asali rajma } \\
\text { (Seto kirmire) }\end{array}$ & Darchula & Khar & $1500-2150$ masl & White with black and red \\
& Rato kirmire & Darchula & Khar & $1500-2150$ masl & Bran Red with white dots \\
\hline KA-17-03-FB & Ankhe thulo & Darchula & Khar & $1500-2150$ masl & Light maroon with black \\
KA-17-04-FB & Batulo sotta & Darchula & Khar & $1500-2150$ masl & Yellow flax \\
\hline KA-17-01-FB & Local kalo & Darchula & Khar & $1500-2150$ masl & Black \\
\hline KA-17-06-FB & & & & &
\end{tabular}

\section{Phenotypic characterization}

Both qualitative and quantitative traits were considered for the characterization of bean landraces. For qualitative traits, we took into account plant type (germination type, plant growth habit and leaf shape), pod characters (immature pod color, pod color at maturity, pod curvature of fully expanded immature pod, pod break orientation, pod break position, pod surface of fully expanded immature pod), seed characters (seed shape and color) and occurrence of disease and pests. For quantitative traits, we considered days to germination, days to flowering, days to pod maturity, seed per pod, 100 seed weight and yield. For each genotype, five plants per replication were measured. The data were noted at regular intervals on all three sites. Scoring and measurements of agro-morphological characters were done based on the international descriptor developed by IBPGR (International Board for Plant Genetic Resources) descriptors for Phaseolus vulgaris (IBPGR 1982).

The date of germination, flowering and pod maturity were recorded based on the $50 \%$ occurrence. The date when $80 \%$ of the pods matured was noted for pod maturity. Node number was recorded after flower set from base to first axillary inflorescence in the indeterminate type and from base to terminal inflorescence in the determinate type. The average was taken from mean of 5 randomly selected plants. The measurement of pod length and width was taken at the broadest part of the pod and measurements were averaged from 5 randomly selected plants of each landrace. The number of seeds per pod was also averaged from 5 randomly selected plants. For the seed weight, 100 healthy seeds were selected and weighed in the weighing machine in seed laboratory of Genebank, NARC and the average weight was taken from 5 samples for each landrace of bean.

\section{Statistical analysis}

The important qualitative characteristics noted for the study were germination type, plant growth type, leaf color, pod color (immature and mature), seed color, seed shape, pod curvature, beak orientation, etc. The quantitative characteristics analyzed were days to germination, days to $50 \%$ flowering, days to $50 \%$ pod maturity, pod length, pod breadth, number of seeds per pod, 100 seed weight and node number. The yield per square meter was calculated and then converted into tons per hectare (t/ha).

The analysis was done using Excel and statistical software R 3.1.3 for Windows. The comparison between varieties and differences in quantitative characteristics in three different sites were done using Krushkal-Wallis test (Kruskal and Wallis 1952). Kruskal-Wallis test, a rank-based nonparametric test, allows comparison among more than two independent samples or groups of an independent variable unlike Mann Whitney test that allows only two samples. Since varieties and sites are independent and their numbers are more than two, we used Kruskal-Wallis test.

\section{RESULTS}

The phenotypic characterization of beans planted in Khar showed significant differences in various characteristics. This means each bean variety has its own significance and character. The analysis of different morphological characters of nine landraces is shown in Table 2 below. 


\section{Qualitative characteristics}

Qualitative characters used in this study such as germination type, plant growth type, leaf shape, immature pod color, pod color at maturity, pod curvature of fully expanded immature pod, pod beak position, pod beak orientation, pod surface of fully expanded immature pod, seed shape and seed color, occurrence of disease and pest are summarized in Table 2. The evaluation of the qualitative variables was carried out based on the descriptors developed by IBPGR (1982).

Table 2. Comparison of bean landraces for various qualitative traits

\begin{tabular}{llllllllllll}
\hline NS & GT & PT & PS & IP & PCM & $\begin{array}{l}\text { PCEI } \\
\text { P }\end{array}$ & PBO & PBP & $\begin{array}{l}\text { Seed } \\
\text { shape }\end{array}$ & $\begin{array}{l}\text { Seed } \\
\text { color }\end{array}$ & $\begin{array}{l}\text { Leaf } \\
\text { shape }\end{array}$ \\
\hline KA-17-08-FB & E & IC & G & NG & Y & SC & St & M & C & PW & T \\
\hline KA-17-07-FB & E & IC & G & CR & R & SC & D & M & C & M & T \\
\hline KA-17-02-FB & E & IC & G & CSG & PYCS & SC & St & NM & C & DRCS & Q \\
\hline KA-17-05-FB & E & IC & P & DG & PY & S & St & M & KS & LB & T \\
\hline KA-17-09-FB & E & IC & G & PSG & Y & S & D & M & C & LBPS & T \\
\hline KA-17-03-FB & E & DBG & G & NG & Y & S & U & NM & KS & RLBS & Q \\
\hline KA-17-04-FB & E & IC & P & NG & Y & C & D & M & C & PBS & R \\
\hline KA-17-01-FB & E & IC & G & NG & Y & S & D & M & Ro & LB & Q \\
\hline KA-17-06-FB & E & IC & G & PSG & PY & S & St & M & C & PB & T \\
\hline
\end{tabular}

Name of Species (NS); Germination Type (GT): Epigeal (E); Plant Type: Indeterminate Climber (IC), Determinate Bushy Growth (DBG); Pod Surface (PS): Glabrous (G), Pubescent (P); Immature pod (IP): Normal Green (NG), Carmine Red (CR), Carmine Stripe on Green (CSG), Dull Green (DG), Purple Stripe on Green (PSG); Pod Colour at Maturity (PCM): Yellow (Y), Red (R), Pale Yellow Colored Stripes (PYCS), Pale Yellow (PY); Pod curvature of expanded immature pod (PCEIP): Slightly Curved (SC), Straight (S), Curved (C); Pod Beak Orientation (PBO): Straight (St), Downward (D), Upward (U); Pod Beak Position (PBP): Marginal (M), Non-marginal (NM); Seed Shape (SS): Cuboid (Cu), Kidney Shaped (KS), Round (R); Seed Color (SCo): Pure white (PW), Maroon (M), Dark red with cream streaks (DRCS), Light Brown (LB), Pure Black (PB), Purple with black streaks (PBS), Red with light brown streaks (RLBS); Leaf Shape: Triangular (T), Quadrangular (Q), Round (R), Light brown with purple streaks (LBPS).

Plant type: All the nine varieties grown for the experiment had an epigeal type of germination which shows that these are all Phaseolus vulgaris L. species. Eight out of nine varieties of beans showed indeterminate climbing growth type and only one variety (KA-17-03-FB) showed determinate bushy growth type. Similarly, five varieties had the triangular shape of leaves, three varieties (KA-17-03-FB, KA-17-01-FB and KA-17-02-FB) had quadrangular shape and KA-17-04-FB had round-shaped leaves.

Pod characteristics: Regarding immature pod color, pods were classified as dark green, normal green, carmine red or other colors. Most of the evaluated genotypes had normal green pods. These were KA-17-08-FB, KA-17-03-FB, KA-17-04-FBand KA-17-01-FB. KA-17-07-FB produced Carmine red pods and KA-17-02-FB had carmine stripe on green pods. Only KA-17-09-FB produced purple stripe on green pods. KA-17-05-FB produced dull green pods. Mature pods or pod color at maturity can be classified as yellow, red or other colors. Most of the evaluated genotypes (five) had yellow colored pods. These were KA-17-08-FB, KA-17-09-FB, KA-17-03-FB, KA-17-04-FB, and KA-17-01-FB. KA-17-07-FB had red-colored matured pods and KA-17-06-FB had pale yellow. Only KA-17-02-FB had pale yellow pods with colored stripes. Likewise, curvature of fully expanded immature pod was categorized as straight, slightly curved, curved (Figure 2). The difference in pods curvature was noted among different varieties. 


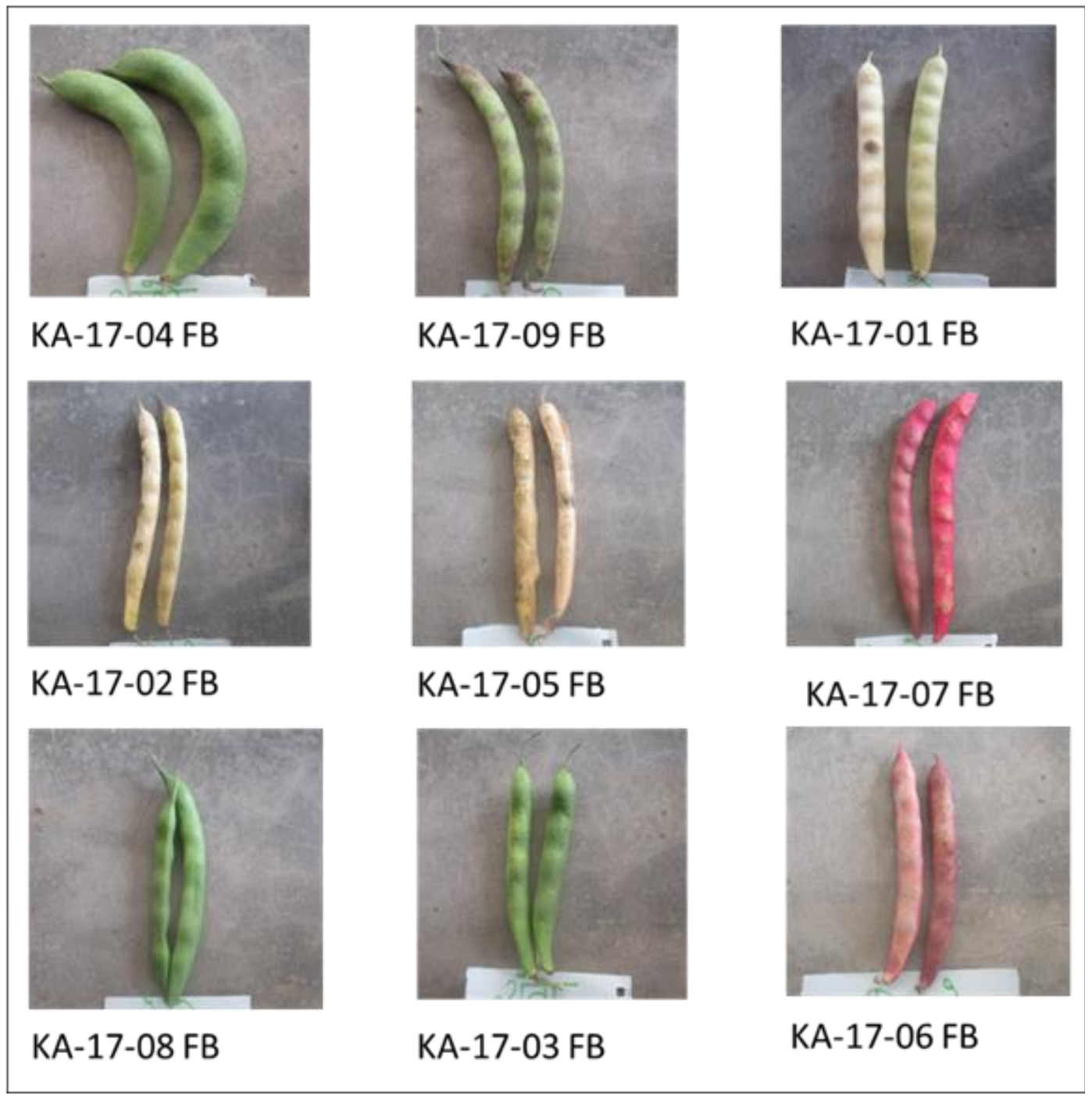

Figure 2. Pod curvature of expanded immature pod.

The position of the pod was straight in KA-17-05-FB, KA-17-03, KA-17-01-FB and KA-17-06-FB, slightly curved in KA-17-08-FB, KA-17-07-FB, KA-17-02-FB and KA-17-09-FB and curved in KA17-04-FB. The results showed that the pod curvature was found the same for slightly curved (4) and straight (4) with only one in a curved category.

Pod beak orientation in beans is upward, downward and straight. Most of the genotypes studied were categorized by straight or downward pod beak orientation. It was upward in KA-17-03-FB, straight in KA-17-08-FB, KA-17-02-FB, KA-17-05-FB and KA-17-06-FB and downward in KA-17-07-FB, KA17-09-FB, KA-17-04-FB and KA-17-01-FB. The pod beak position is categorized as marginal and non- marginal. The pod beak orientation was straight orientation in 4, downwards in 4 and upwards in only one variety. The position of pod beak was marginal in seven varieties: KA-17-08-FB, KA-17-07FB, KA-17-09-FB, KA-17-05-FB, KA-17-04-FB, KA-17-01-FB and KA-17-06-FB and nonmarginal in 2 varieties which are KA-17-02-FB and KA-17-03-FB.

When the surface of fully expanded immature pod of all the varieties were analyzed, seven varieties had glabrous surface (smooth surface without hair) which are KA-17-08-FB, KA-17-07-FB, KA-1702-FB, KA-17-09-FB, KA-17-03-FB, KA-17-01-FB and KA-17-06-FB and two varieties namely KA-17-05-FB and KA-17-04-FB had pubescent pod surface (hairy surface). 
Seed characteristics: Regarding seed shape and color, out of 9 varieties, six varieties had cuboid seed shape (KA-17-08-FB, KA-1707-FB, KA-17-02-FB, KA-17-09FB, KA-17-04-FB and KA-17-06FB), one round shape (KA-17-01FB) and two kidney-shaped (KA17-05-FB and KA-17-03-FB). All the nine varieties had variable seed color which is one of the identifying characteristics and all the local names are derived based on the seed color (Figure 3). Three varieties had only one colored seed color i.e. KA-17-08-FB, KA-17-01-FB and KA-17-06-FB. All other varieties had two colors one of which was dark-colored and the other was lightcolored.

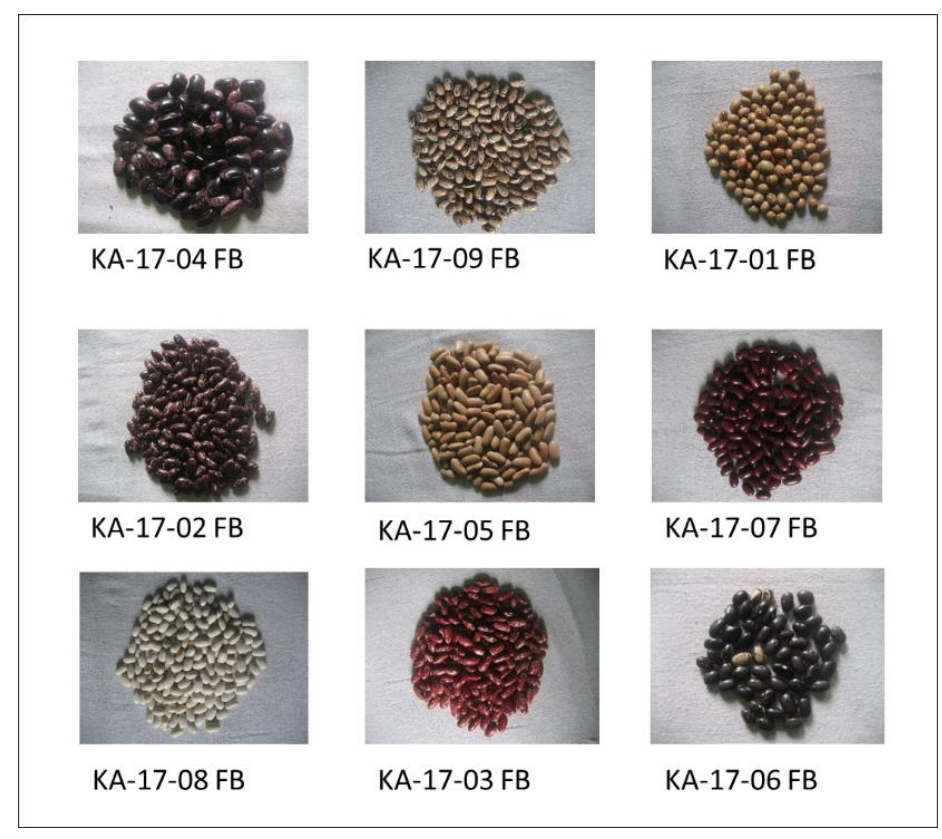

Figure 3. Seed shape and color of beans landraces.

Occurrence of disease and pests: The occurrence of diseases and pest were found different in different varieties of beans as shown in Table 3. Only three varieties namely KA-17-07-FB, KA-1704-FB and KA-17-06-FB were found to be pest and disease resistant in all three sites. KA-17-08-FB suffered with dark spots in pods and the pods could not mature properly. For KA-17-09-FB in Dallekh site, pods turned black and pest was seen. In KA-17-05-FB, pest was seen and green pods dried due to disease in all three sites. Other varieties such as KA-17-02-FB, KA-17-03-FB and KA-17-01-FB suffered little harm from the pest.

Table 3. Name of varieties with the occurrence of disease and pest in three sites

\begin{tabular}{lcccc} 
Name of the & \multicolumn{4}{c}{ Occurrence of disease/pest } \\
\cline { 2 - 5 } varieties & Dhamidera & Sundamunda & Dallekh \\
\hline KA-17-08-FB & + & + & - & + (dark spots in pods) \\
\hline KA-17-07-FB & - & + & - \\
\hline KA-17-02-FB & + & + (pods dried of disease) & + (pods dried of disease) \\
\hline KA-17-05-FB & + (pods dried of disease) & - & + (green pods turned black) \\
\hline KA-17-09-FB & - & + & + \\
\hline KA-17-03-FB & + & - & - \\
\hline KA-17-04-FB & - & + & + \\
\hline KA-17-01-FB & + & - & - \\
\hline KA-17-06-FB & - & &
\end{tabular}

\section{Quantitative characteristics}

Plant growth behavior: Days to germination determines which variety germinates early and which germinates late. All the varieties took 3 to 4 days to germinate in Dhamidera and 4 to 6 days in Sundamunda and Dallekh (Table 4). The 50\% flowering dates differed in different varieties and in three sites. The 50\% flowering occurred earliest in Dhamidera in all the varieties and late in Dallekh. KA-17-08-FB and KA-17-04-FB were very late flowering varieties compared to all other varieties which normally took fewer days to flower. In Dhamidera, KA-17-08-FB took 61 days and KA-17-04FB took 63 days and the other seven varieties flowered 50\% between 40 to 42 days. In Sundamunda, KA-17-08-FB took 65 days and KA-17-04-FB took 66 days and others took 40 to 45 days to flower $50 \%$. In Dallekh, KA-17-08-FB took 64 days and KA-17-04-FB took 67 days and other varieties took 42 to 46 days. In average in all three sites, KA-17-08-FB (Seto sotta) and KA-17-04-FB (Ankhe 
thulo) took 63 and 65 days respectively as compared to 40 to 46 days to flower for rest of the landraces. All other varieties belonged to medium maturing category.

Regarding days to pod maturity, days to $50 \%$ pod maturity of a particular variety also describes whether the variety is early, medium or late-maturing and determines which varieties can be harvested early. Days to $50 \%$ pod maturity varied in different varieties and the three sites as well. The pod maturity occurred earliest in Dhamidera in all varieties and Sundamunda a bit late and very late in Dallekh. In Dhamidera, KA-17-08-FB and KA-17-04-FB took 96 days and KA-17-01-FB took 92 days for $50 \%$ pod maturity which were very late maturing compared to other varieties which took 72 to 77 days for pod maturity. In Sundamunda, KA-17-08-FB and KA-17-04-FB took 98 days and KA17-01-FB took 97 days while other varieties took 76 to 80 days to pod maturity. In Dallekh, KA-1708-FB took 102 days and KA-17-04-FB and KA-17-01-FB took 98 and 96 days respectively, while other varieties pod matured in 79 to 85 days.

Seed characteristics: Different varieties had the different numbers of seeds per pod which shows each variety had a distinct number of seeds per pod. Five varieties (KA-17-08-FB, KA-17-07-FB, KA-17-02-FB, KA-17-01-FB and KA-17-06-FB out of nine had 7 seeds per pod which was more or less consistent in all the three sites. Only KA-17-05-FB variety had five seeds per pod in all the three sites and KA-17-09-FB had 6 seeds per pod. The lowest number of seeds per pod was of KA-17-04FB which had considerably larger seeds which might be the reason for having only four seeds per pod. Different varieties had different 100 seed weight. Local kalo KA-17-06-FB had the lowest 100 seed weight $(30.32 \mathrm{~g})$ and KA-17-04-FB had the highest weight of $98.03 \mathrm{~g}$. Six varieties had 100 seed weight between 30 to $50 \mathrm{~g}$ and two varieties had between 50 to $70 \mathrm{~g}$ Large seeded genotypes were KA-17-04-FB (98.03 g), KA-17-02-FB(51.225 g) and KA-17-05-FB (64.33 g) having 100 seed weight $>50 \mathrm{~g}$.

Table 4. Mean performance of various parameters of evaluated landraces in three sites

\begin{tabular}{|c|c|c|c|c|c|c|c|c|c|}
\hline Characteristics & 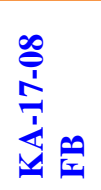 & 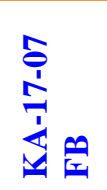 & 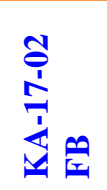 & 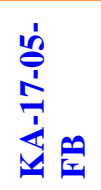 & $\frac{g}{\grave{c}}$ & 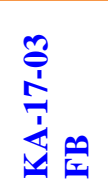 & 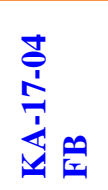 & 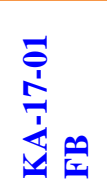 & 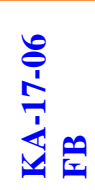 \\
\hline \multicolumn{10}{|l|}{ Dhamidera } \\
\hline Days to germination & 4.3 & 4.67 & 5 & 5 & 5 & 5 & 5.67 & 6 & 3 \\
\hline Days to $50 \%$ flowering & 61 & 41 & 49 & 41 & 49 & 46 & 63 & 41 & 40.33 \\
\hline Days to $50 \%$ pod maturity & 96 & 61 & 69 & 68.67 & 70 & 74 & 96 & 92.67 & 74 \\
\hline Days to $90 \%$ pod maturity & 109 & 104 & 104 & 104 & 104 & 104 & 104 & 104 & 104 \\
\hline Pod number, $\mathrm{n}$ & 9.16 & 23.3 & 31.3 & 32.33 & 18.33 & 16.67 & 9.5 & 29.67 & 13.67 \\
\hline Pod length, cm & 12.56 & 14.4 & 17.03 & 16.86 & 11.83 & 13.16 & 15.37 & 14.23 & 12.67 \\
\hline Pod breadth, $\mathrm{cm}$ & 1 & 1.5 & 1.5 & 1.5 & 1 & 1 & 2.5 & 1.5 & 2 \\
\hline Seed per pod, $n$ & 7 & 7 & 7 & 5 & 6.33 & 4 & 4 & 7 & 7 \\
\hline 100 seed weight $(\mathrm{g})$ & 32 & 37.87 & 51.22 & 64.33 & 37.18 & 44.96 & 98.03 & 48.93 & 30.32 \\
\hline \multicolumn{10}{|l|}{ Sundamunda } \\
\hline Days to germination & 4.33 & 4.33 & 5 & 5 & 5 & 5 & 5.67 & 6 & 5 \\
\hline Days to $50 \%$ flowering & 65 & 41 & 49 & 41 & 49 & 46 & 66 & 41 & 41 \\
\hline Days to $50 \%$ pod maturity & 98 & 67.33 & 70 & 69.67 & 70.67 & 76.33 & 98 & 91 & 75 \\
\hline Days to $90 \%$ pod maturity & 109 & 104 & 104 & 104 & 106 & 104 & 104 & 104 & 104 \\
\hline Pod number, n & 12.33 & 17 & 29.33 & 19.33 & 15.67 & 12.67 & 7.83 & 23 & 12 \\
\hline Pod length, $\mathrm{cm}$ & 13.4 & 14.06 & 17.1 & 16.67 & 11.46 & 12.3 & 14.16 & 14.13 & 11.67 \\
\hline Pod breadth, cm & 1 & 1 & 1.5 & 1.5 & 1 & 1 & 2.5 & 1.5 & 2 \\
\hline
\end{tabular}




\begin{tabular}{|c|c|c|c|c|c|c|c|c|c|}
\hline Characteristics & 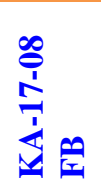 & 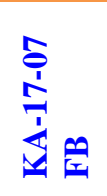 & 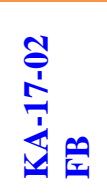 & $\frac{n}{1}$ & $\frac{\partial}{\stackrel{1}{a}}$ & 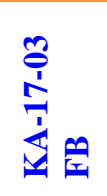 & 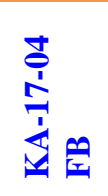 & 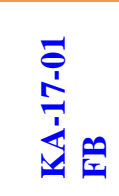 & 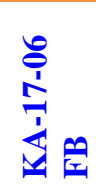 \\
\hline Seed per pod, $n$ & 6.67 & 7 & 7 & 5 & 6 & 4 & 4 & 7 & 7 \\
\hline 100 seed weight $(\mathrm{g})$ & 33 & 37.2 & 50.67 & 63.76 & 36.43 & 44.53 & 97.36 & 49 & 29.73 \\
\hline \multicolumn{10}{|l|}{ Dallekh } \\
\hline Days to germination & 4 & 5 & 4.3 & 4.67 & 4.3 & 4.3 & 4.67 & 5 & 5 \\
\hline Days to $50 \%$ flowering & 64 & 42 & 41 & 41 & 41 & 43 & 67 & 42.3 & 41 \\
\hline Days to $50 \%$ pod maturity & 102 & 67.3 & 90 & 69.67 & 71.67 & 75 & 98 & 96 & 75 \\
\hline Days to $90 \%$ pod maturity & 109 & 104 & 104 & 94 & 104 & 97 & 104 & 104.67 & 104 \\
\hline Pod number, $\mathrm{n}$ & 9.67 & 14 & 20.33 & 18 & 12 & 15.33 & 10.33 & 20.67 & 12.67 \\
\hline Pod length, cm & 13.93 & 15 & 16.93 & 15.67 & 11.67 & 12.83 & 12.9 & 14.56 & 12 \\
\hline Pod breadth, cm & 1 & 1.5 & 1.78 & 1.5 & 1 & 1.93 & 2.16 & 2.1 & 1.93 \\
\hline Seed per pod, $\mathrm{n}$ & 7 & 8.3 & 6 & 5 & 5.67 & 4 & 4 & 7 & 7 \\
\hline 100 seed weight $(\mathrm{g})$ & 35.33 & 36.76 & 51.4 & 63.36 & 37 & 43.43 & 96.95 & 48.51 & 30.3 \\
\hline
\end{tabular}

Yield parameters: The yield for all the nine varieties was calculated and significant differences were noted. There was a significant difference in yield in three sites as well. All the varieties except KA17-08-FB (highest in Sundamunda) had the highest yield in Dhamidera compared to Dallekh and Sundamunda. This shows that the increase in temperature leads to good production of beans in Dhamidera than in Sundamunda and Dallekh. KA-17-02-FB had the highest yield of 4.48(t/ha) in Dhamidera and $4.16(\mathrm{t} / \mathrm{ha})$ in Sundamunda and had the highest yield of $2.80(\mathrm{t} / \mathrm{ha})$ in dallekh. KA-17$02-\mathrm{FB}$ was the best yielding variety among the nine varieties. Among nine varieties, KA-17-08-FB had the lowest yield in two sites i.e. Dhamidera (0.82 t/ha) and Dallekh $(0.95 \mathrm{t} / \mathrm{ha})$ and KA-17-03-FB $(0.90 \mathrm{t} / \mathrm{ha}) \mathrm{had}$ the lowest yield in Sundamunda. Varieties yielding more than $2 \mathrm{t} / \mathrm{ha}$ in Dhamidera were: KA-17-07-FB, KA-17-02-FB, KA-17-05-FB and KA-17-01-FB and both in Sundamunda and Dallekh were: KA-17-02-FB, KA-17-05-FB and KA-17-01-FB. Eighty-nine percent of varieties produced more than $1.0 \mathrm{t} / \mathrm{ha}$ seed yield in Dhamidera and Dallekh and seventy-eight percent in Sundamunda.

Pod characteristics: The number of pods is of major importance in case of bean yield and selection of a variety. KA-17-05-FB had the highest number of pods (32) in Dhamidera, whereas KA-17-02-FB performed best with 29 pods in the Sundamunda site and KA-17-01-FB (21) had highest in Dallekh site. In both Dhamidera and Dallekh, KA-17-08-FB had least number of pods i.e. 9 and 10 and KA17-04-FB had least in Sundamunda site (8). In terms of production of pods, KA-17-08-FB was found to be the least productive. As the local people from Khar had also complained that KA-17-08-FB does not perform well compared to other bean varieties despite being an older variety.

Average pod length in three sites showed a significant difference in different genotypes. In all three sites, KA-17-02-FB produced the longest pods $(17.03 \mathrm{~cm}, 17.1 \mathrm{~cm}$ and $16.93 \mathrm{~cm})$ in Dhamidera, Sundamunda and Dallekh respectively and the shortest pods were of KA-17-09-FB in all three sites. The results display clearly that the pod length of the variety was influenced by the genotype. Pod width also varied in different genotypes. The widest pods were produced by KA-17-04-FB $(2.5 \mathrm{~cm})$. All other genotype's pod width ranged from $1 \mathrm{~cm}$ to $2 \mathrm{~cm}$.

Table 5. Kruskal-Wallis test for characteristics studied in different varieties in the study sites Characteristics Kruskal-Wallis test 


\begin{tabular}{|c|c|c|c|}
\hline \multirow[t]{2}{*}{ Characteristics } & \multicolumn{3}{|c|}{ Kruskal-Wallis test } \\
\hline & Chi- square value & df & p value \\
\hline Days to $50 \%$ pod maturity vs varieties & 58.204 & 8 & $<0.0001$ \\
\hline Pod number vs varieties & 55.5019 & 8 & $<0.0001$ \\
\hline Pod length vs varieties & 65.685 & 8 & $<0.0001$ \\
\hline Pod breadth vs varieties & 15.1108 & 8 & 0.057 \\
\hline 100 seed weight vs varieties & 78.137 & 8 & $<0.0001$ \\
\hline Seed per pod vs varieties & 17.2299 & 8 & 0.027 \\
\hline Number of nodes vs varieties & 38.0316 & 8 & $<0.0001$ \\
\hline Yield vs varieties & 22.8042 & 8 & 0.003 \\
\hline \multicolumn{4}{|c|}{$\begin{array}{l}\text { Table 6. Kruskal-Wallis test for characteristics studied in three sites (Dhamidera, Sundamunda and } \\
\text { Dallekh) }\end{array}$} \\
\hline \multirow[t]{2}{*}{ Characteristic } & \multicolumn{3}{|c|}{ Kruskal-Wallis test } \\
\hline & Chi- square value & df & p value \\
\hline Days to germination vs site & 35.8277 & 2 & $<0.0001$ \\
\hline Days to $50 \%$ flowering vs site & 16.4558 & 2 & 0.0002 \\
\hline Days to $50 \%$ pod maturity vs site & 18.8176 & 2 & $<0.0001$ \\
\hline Pod number vs site & 5.2943 & 2 & 0.07 \\
\hline Pod length vs site & 0.5604 & 8 & $<0.0001$ \\
\hline Pod breadth vs site & 39.5209 & 2 & $<0.0001$ \\
\hline 100 seed weight vs site & 0.2311 & 2 & 0.89 \\
\hline Seed per pod vs site & 33.9386 & 2 & $<0.0001$ \\
\hline Number of nodes vs site & 5.494 & 2 & 0.064 \\
\hline
\end{tabular}

Kruskal- Wallis test was performed to find out whether there are significant differences between the nine varieties and the different characteristics measured and also to see the differences in different plots as shown in Table 5 and Table 6. Significant differences were noted between the varieties and the characteristics. Among the ten characteristics compared with the varieties, except days to germination, all studied traits showed significant variation among the genotypes. Similarly, KruskalWallis test was also performed to find out whether there is a statistically significant difference between each variety's characteristics in three different sites as shown in Table 4. Analyzing all the characteristics for KA-17-08-FB showed that only three characteristics (days of 50\% flowering, days of 50\% pod maturity and node number) showed a difference in terms of site. In case of KA-17-07-FB, five characteristics (days of 50\% flowering, days of 50\% pod maturity, pod number, pod breadth and seed per pod) were significantly different in three sites.

KA-17-02-FB had also differences in days of 50\% flowering and pod maturity, pod number, pod breadth, seed per pod and node number in three sites. For KA-17-05-FB, there were differences in days of germination, days of 50\% flowering and pod maturity and node number. In the case of KA17-09-FB, days of 50\% flowering, pod maturity and pod number had a difference in three sites. KA17-03-FB showed differences in days of germination, days of 50\% flowering, pod maturity and pod breadth. Days of germination, days of 50\% flowering, pod maturity and node number showed differences in three sites for KA-17-04-FB. For KA-17-01-FB, days of germination, days of 50\% flowering and pod maturity. KA-17-06-FB had differences in days of germination, days of 50\% flowering and days of 50\% pod maturity. Most of the varieties had differences in flowering days and pod maturity in three sites as the elevation might play an important rolein the flowering and maturation of the pods of the varieties.

\section{DISCUSSION}

Beans are locally called "sotta" and are an integral part of the diet of the people of Khar. They are consumed as whole seeds or in grinded forms, both as curry or 'daal'. These are usually planted by mixing all the varieties together. Beans, regarded as healthy proteins, are consumed by all households. Indeed, black bean soup is given to their sick as an energy supplement. Today, farmers of Khar VDC grow early maturing bean varieties of larger seed sizes that fetch good market value (Aryal et al 2017). Farmers in Nepal preferred bean landraces that are medium growth habit, early maturing 
nature, high yielding, good seed size and color and are high demand in the market (Chhetri and Bhatta 2017, Neupane et al 2008). A similar study was done in bean growing area in Malawi to understand the farmer's specifications for variety selection showed that farmers looked on grain color, cooking time, taste, grain size as well as grain brightness to choose the varieties (Chirwa and Phiri 2005).

We observed agro-morphological variations in the local varieties planted in three sites which shows that there is scope for selection of suitable landraces in the study area, which corroborate with the observations and inferences made by Razvi et al (2018). Similarly, Stoilova et al. (2006) found that out of many accessions studied, some accessions with an erect habit, a shorter period to reach maturity had higher number of pods and seeds per plant as these genotypes escaped unfavorable conditions of high daily temperature and low humidity during the flowering and pod formation periods. A combination of agro-morphological and molecular data collection methods for plant germplasm is also suggested by Chiorato et al (2006) and Lyngdoh et al (2018) but our study had a limitation to do this. In our study too, the same variety had different flowering and pod maturity times even they were planted on the same date. Flowering and pod maturity occurred earliest for all the varieties in the lower elevation site (Dhamidera), followed by the middle (Sundamunda) and highest site (Dallekh). This clearly indicates the environment particularly the temperature played an important role in physiological and phenological growth of the varieties included in the study. Similar study on 70 common bean landraces of Mexico showed there were significant differences in the morphological and physiological traits of the plant, pod and grain among different geographic regions which were also associated with different indigenous groups (Chavez-Servia et al 2016).

KA-17-08-FB and KA-17-04-FB are very late flowering and maturing landraces. This is one of the reasons local people preferred less compared with landraces like KA-17-07-FB which flowered earliest (within 42 days in all the three sites) which shows it is an early maturing variety. It might be because, due to an early onset of winter in the high altitude, the late maturing variety cannot complete the life cycle or cannot give proper yield due to cold stress (Neupane et al 2008). There was a difference in the pod yield of the nine varieties. KA-17-08-FB had the lowest yield in both Dhamidera and Dallekh and KA-17-03-FB had lowest in Sundamunda. The local varieties such as KA-17-06-FB and KA-17-08-FB are disappearing perhaps due to low yield although the later is considered as the most delicious variety. KA-17-08-FB can be promoted using awareness, value addition and market linkage techniques. The most successful variety in terms of yield was KA-17-02-FB having the highest yield in Dhamidera and Sundamunda and KA-17-01-FB got highest in Dallekh. Thus, KA-1701 and KA-17-02 can go for scaling up in the region and in similar environments in the country. A similar study on the evaluation of 12 varieties of P. vulgaris by Gereziher et al 2017 from Raya valley, Northern Ethiopia showed Nasir variety performing well compared to other varieties to the valley conditions and was recommended for scaling up and widespread dissemination.

\section{CONCLUSION}

A variety of beans with diverse agro-morphologies are grown in different agro-ecological zones in Nepal which gives an opportunity for crop improvement and material exchange. Our attempt to assess diversity suggests that variations in beans occur in both quantitative and qualitative traits. They differ in germination, flowering and maturity time as well as pod, plant and seed characteristics. Differences were also observed in disease resistance and yield. These were the basis for farmers to choose one variety over the other. Therefore, there is an opportunity to select high yielding, early maturing, disease-resistant and locally preferred varieties from the locality. The variations also indicate the possibility of producing new varieties with combined traits transferred from different varieties through breeding methods (eg crossing).

Variation has also been observed among locations, which is likely due to environmental differences between the locations. This clearly suggests that materials can be exchanged between sites and adaptive research can be done to assess the adaptability of different landraces varieties. An appropriate seed supply system needs to be established for proper seed production and exchange between different ecological zones. 


\section{ACKNOWLEDGEMENTS}

Authors wish to thank farmers of the study sites who provided the land and moral support for the research. We also would like to thank Mr Shankar Badal and Ms Sita Mahara from Khar for their support on regular data collection and monitoring of the research plots. Thank is also due to all the farmers who participated during various stages of the research. We would like to thank National Genebank who provided technical support for characterization, passport data collection as well as getting accession numbers. We would like to acknowledge the support from Department for International Development (DFID)-UK Aid, German Federal Ministry of Economic Cooperation and Development, and German International Cooperation (GIZ) under the Kailash Sacred Landscape Conservation and Development Initiative (KSLCDI) programme coordinated by International Centre for Integrated Mountain Development (ICIMOD). Partial funding came from ICIMOD's core fund contributed by different member countries. Last but not least we wish to thank Api-Nampa Conservation Area Office under Department of National Park and Wildlife Conservation, Government of Nepal for coordination of this research at field level.

\section{DISCLAIMER}

The views and interpretations in this publication are those of the authors and they are not necessarily attributable to their organizations.

\section{REFERENCES}

Aryal K, S Poudel, RP Chaudhary, N Chettri, W Ning, Y Shaoliang and R Kotru. 2017. Conservation and management practices of traditional crop genetic diversity by the farmers: A case from Kailash Sacred Landscape, Nepal. Journal of Agriculture and Environment 18: 15-28.

Chavez-Servia JL, E Heredia-Garcia, N Mayek-Perez, EN Aquino-Bolanos, S Hernandez-Delgado, JC CarrilloRodriguez HR Gill-Langarica and AM Vera-Guzman.2016. Diversity of common bean (Phaseolus vulgaris L.) landraces and the nutritional value of their grains. Grain Legumes. In Tech, Rijeka, Croati; pp. $1-33$

Chhetri A and A Bhatta. 2017. Agro-Morphological Variability Assessment of Common Bean (Phaseolus vulgaris L.) Genotypes in High Hill Jumla, Nepal. International Journal of Environment, Agriculture and Biotechnology 2(6): 3110-3115

Chiorato AF, SAM Carbonell, LADS Dias, RR Moura, MB Chiavegato, and CA Colombo. 2006. Identification of common bean (Phaseolus vulgaris) duplicates using agromorphological and molecular data. Genetics and Molecular Biology 29(1): 105-111

Chirwa R and M Phiri. 2005. Factors that influence demand for beans in Malawi. CIAT Online Library. https://cgspace.cgiar.org/bitstream/handle/10568/72302/Factors_affecting_demand_for_beans.pdf?sequenc $\mathrm{e}=1$

Gereziher T, E Seid and G Bisrat. 2017. Performance evaluation of common bean (Phaseolus vulgaris L.) varieties in Raya Valley, Northern Ethiopia. African Journal of Plant Science 11(1):1-5.

IBPGR. 1982. Descriptor List for Phaseolus vulgaris L. International Board for Plant Genetic Resources, Rome.

Joshi BK, AK Acharya, D Gauchan and MR Bhatta. 2017a. Agrobiodiversity status and conservation options and methods. In: Conservation and Utilization of Agricultural Plant Genetic Resources in Nepal (BK Joshi, HB KC and AK Acharya, eds). Proceedings of 2nd National Workshop, 22-23 May 2017, Dhulikhel; NAGRC, FDD, DoA and MoAD; Kathmandu, Nepal; pp. 21-38. http://moad.gov.np/public/uploads/855517450-Plant\%20Genetic\%20Resources_CUAPGR_Nepal-min.pdf

Joshi BK, MR Bhatta, KH Ghimire, M Khanal, SB Gurung, R Dhakal, and BR Sthapit. 2017b. Released and Promising Crop Varieties of Mountain Agriculture in Nepal (1959-2016). LI-BIRD, Pokhara; NARC, Kathmandu and Bioversity International, Pokhara, Nepal.

KC RB, BK Joshi and SP Dahal. 2016. Diversity analysis and physico-morphological characteristics of indigenous germplasm of lablab bean. Journal of Nepal Agricultural Research Council 2:15-21. https://www.nepjol.info/index.php/JNARC/article/view/16116

Kruskal WH and WA Wallis. 1952. Use of ranks in one-criterion variance analysis. Journal of the American statistical Association 47(260):583-621.

Lyngdoh YA, U Thapa, A Shadap, J Singhand BS Tomar.2018. Studies on genetic variability and character association for yield and yield related traits in french bean (Phaseolus vulgaris L.). Legume Research-An International Journal 41 (6): 810-815

Muchui MN, A Ndegwa, S Wachiuri, B Muthama and J Kimamira. 2008. Post-harvest evaluation of introduced French bean (Phaseolus vulgaris L.) varieties. African Journal of Horticultural Science 1:116-120 
Neupane RK and ML Vaidya. 2002. Development of improved production technology of Phaseolus beans to the hills of mid-western Nepal. In: Proceedings of the First Stakeholders' Meeting. NGLRP, Rampur; pp. 511.

Neupane RK, R Shrestha, ML Vaidya, EM Bhattarai and R Darai. 2008. Agro morphological diversity in common bean (Phaseolus vulgaris L.) landraces of Jumla, Nepal. In Proceedings of the Fourth International Food Legumes Research Conference. New Delhi, India; pp. 639-648.

Pandey YR, DM Gautam, BR Thapa, DM Sharma, and PK Paudyal. 2011. Variability of French bean in the Western Mid hills of Nepal. Kasetsart J. (Nat. Sci) 45:780-792.

Pandey YR, DM Gautam, RB Thapa, MD Sharma and KP Paudel. 2012. Response of Pole Type French Bean (Phaseolus vulgaris L.) Genotypes to Sowing Dates in the Mid Hills of Western Nepal. Nepal Journal of Science and Technology 13 (2): 15-20.

Razvi SM, MN Khan, MA Bhat, M Ahmad, SA Ganaie, FA Sheikh and FA Parry. 2018. Morphological variability and phylogenetic analysis in Common bean (Phaseolus vulgaris L.). Legume Research-An International Journal 41(2): 208-212.

Sheikh AA, N Jabeen, AA Sheikh, N Yousuf, SU Nabi, TA Bhat and PA Sofi. 2017. Evaluation of French Bean Germplasm Based on Farmer Specified Attributes through Participatory Varietal Selection (PVS) In Kashmir Valley. Int. J. Pure App. Biosci 5(2): 585-594.

Shrestha G, KB Karki and GD Bhatta. 2008. Role of Legume Intercropping in Sustainable Farming in Mid Hills of Nepal. Agricultural Research for Poverty Alleviation and Livelihood Enhancement 27.

Shrestha R, RK Neupane and NP Adhikari. 2011. Status and Future Prospects of Pulses in Nepal. In: Regional Workshop on Pulse Production held at Nepal Agricultural Research Council (NARC), Kathmandu; pp.2425.

Stoilova T, G Pereira, MM de Sousaand and V Carnide. 2006. Diversity in common bean landraces (Phaseolus vulgaris L.) from Bulgaria and Portugal. Journal of Central European Agriculture 6(4): 443-448.

$|1------1|------1 \mid$ 